\title{
PENGGUNAAN MEDIA PEMBELAJARAN INTERAKTIF DAN KOMUNIKASI INTERPERSONAL TERHADAP HASIL BELAJAR KIMIA
}

\author{
Hendra dan Sahat Siagian \\ SMA Swasta Sutomo 2 Medan dan PPs Universitas Negeri Medan \\ hendra@gmail.com
}

\begin{abstract}
Abstrak: Penelitian ini bertujuan untuk mengetahui mengetahui perbedaan hasil belajar kimia antara siswa yang dibelajarkan dengan menggunakan media pembelajaran interaktif online dan media pembelajaran interaktif offline, perbedaan hasil belajar siswa yang memiliki komunikasi interpersonal terbuka dan komunikasi interpersonal tertutup, interaksi antara penggunaan media pembelajaran interaktif dan komunikasi interpersonal dalam mempengaruhi hasil belajar kimia siswa. Penelitian ini merupakan penelitian kuasi eksperimen. Menyajikan dan mendeskripsikan data digunakan statistik deskriptif, menguji hipotesis digunakan statistik inferensial dengan ANAVA dua jalur yang sebelumnya dilakukan uji persyaratan normalitas dan uji homogenitas varians. Hasil penelitian diperoleh bahwa hasil belajar kimia siswa yang dibelajarkan dengan menggunakan media pembelajaran interaktif online lebih tinggi dibandingkan dengan hasil belajar kimia siswa yang dibelajarkan dengan menggunakan media pembelajaran interaktif offline, hasil belajar kimia siswa yang memiliki komunikasi interpersonal terbuka lebih tinggi dibandingkan dengan siswa yang memiliki komunikasi interpersonal tertutup, dan terdapat interaksi antara penggunaan media pembelajaran interaktif dengan komunikasi interpersonal dalam mempengaruhi hasil belajar kimia.
\end{abstract}

Kata Kunci: multimedia interaktif model tutorial, multimedia interaktif model linier, kecerdasan visual-spasial, kecerdasan kinestetik

\begin{abstract}
This study aims to determine the chemical determine differences in learning outcomes between students who learned with using interactive learning media online and offline media interactive learning, differences in learning outcomes of students who have interpersonal communication open and closed interpersonal communication, interaction between the use of interactive learning media and interpersonal communication in affect the chemistry student learning outcomes. This study was a quasi-experimental research. Presenting and describing data used descriptive statistics, inferential statistics were used to test the hypothesis with two paths before ANOVA test requirements of normality and homogeneity of variance test. The results showed that the learning outcomes of students that learned chemistry using an online interactive learning media is higher than the learning outcomes of students that learned chemistry using offline media interactive learning, learning outcomes chemistry students who have interpersonal communication open is higher than students who have communication interpersonal closed, and there was an interaction between the use of interactive learning media with interpersonal communication in influencing the outcome of learning chemistry.
\end{abstract}

Keywords: interactive multimedia of tutorial model, interactive multimedia of linear model, visual-spatial intelligence and kinesthetic intelligence

\section{PENDAHULUAN}

Pada dasarnya peningkatan mutu pendidikan menjadi kewajiban semua pihak yang terlibat dalam bidang pendidikan. Salah satu usaha dalam peningkatan mutu pendidikan yang sesuai dengan perkembangan ilmu pengetahuan dan teknologi (IPTEK) serta era globalisasi adalah adanya penggunaan media pembelajaran interaktif berbasis pada kemajuan teknologi informasi dan komuniksi (TIK). Hal ini memungkinkan kegiatan belajar mengajar dapat dilaksanakan secara efektif dan efisien sehingga tujuan yang telah ditetapkan dapat tercapai dengan baik. Untuk itu setiap guru dituntut agar tetap meningkatkan kualitas yang dimilikinya baik dalam pengetahuan maupun kreatifitasnya dalam merancang media pembelajaran interaktif yang digunakan dalam menyampaikan materi pelajaran sehingga hasil belajar yang tercapai dapat optimal. 
Dalam kaitan dengan penggunaan media pembelajaran interaktif, maka yang menjadi perhatian bagi setiap guru adalah bagaimana seorang guru mampu memilih dan menggunakan serta menyesuaikan dengan materi, sifat dan karakteristik ilmu pengetahuan serta karakteristik dari siswa. Penggunaan media dalam pembelajaran bertujuan untuk membantu siswa dalam penguasaan materi pelajaran dan memiliki keterampilan. Dalam hal ini guru harus benar-benar mampu mendesain proses pembelajaran dan menentukan materi yang akan disampaikan dan dengan media apa disajikan.

Melihat data yang ada pada SMA Swasta Sutomo 2 Medan, bahwa hasil belajar mata pelajaran Kimia kelas $\mathrm{X}$, belum memuaskan. Hal ini dapat dilihat dari hasil ujian semester ganjil 285 orang siswa yang terdiri dari 5 kelas dengan tingkat ketuntasan minimal pada nilai 6,5 .

Rendahnya rata-rata perolehan nilai tersebut tentunya dimungkinkan rendahnya penguasaan materi oleh siswa. Di samping itu, kegiatan pembelajaran Kimia di SMA Swasta Sutomo 2 Medan masih berjalan secara konvensional, di mana masih didominasi kegiatan ceramah dan berpusat pada guru. Dari hasil penelitian awal yang telah dilakukan, ditemukan bahwa kecenderungan guru melaksanakan pembelajaran selalu dilakukan melalui satu teknik penyampaian saja, sehingga kurang menarik perhatian siswa dan akhirnya menyebabkan siswa merasa bosan ketika pelajaran berlangsung. Permasalahan tersebut di atas pada akhirnya tentu akan berpengaruh terhadap hasil belajar siswa. Hasil belajar Kimia tentunya memiliki pengaruh terhadap hasil belajar secara keseluruhan. Di samping kurangnya penggunaan media pembelajaran interaktif yang tepat, rendahnya perolehan hasil belajar Kimia siswa juga dipengaruhi oleh karakteristik siswa itu sendiri yaitu komunikasi interpersonal (antar pribadi), hal ini dapat dilihat dari kurangnya interaksi siswa pada saat proses pembelajaran berlangsung. Siswa kurang aktif bertanya, hanya menerima apa yang disampaikan oleh guru. Tidak aktif dalam mencari materi-materi tambahan baik melalui buku-buku maupun melalui internet.

Melihat hal tersebut di atas, maka diperlukan perbaikan-perbaikan proses pembelajaran secara terus menerus, sehingga siswa lebih termotivasi, lebih aktif dan juga memiliki komunikasi interpersonal dalam mempelajari mata pelajaran Kimia, sehingga dapat meningkatkan hasil belajar. Salah satu upaya yang dapat dilakukan adalah dengan penggunaan media pembelajaran interaktif, sehingga dapat mendorong siswa lebih mudah dalam memahami konsep-konsep pembelajaran Kimia.

\section{Melalui E-Learning Moodle (Modular}

Object Oriented Dynamic Learning Environment) yang merupakan salah satu dari Learning Management System (LMS) diharapkan dapat meningkatkan efisiensi proses belajar mengajar, meningkatkan motivasi, memfasilitsasi belajar aktif, memfasilitasi belajar eksperimental, konsisten dengan belajar berpusat pada siswa, memandu belajar lebih baik, serta belajar dengan keinginan sendiri dan dengan kecepatan yang disesuaikan sendiri meningkatkan pemahaman akan isi (MPB TIK 2010).

Selain penggunaan media pembelajaran interaktif, guru juga harus dapat memperhatikan komunikasi interpersonal yang dimiliki oleh siswa. Keberhasilan belajar tergantung bagaimana siswa dapat menyampaikan kemampuan akan analisisnya terhadap pembelajaran Kimia yang pada akhirnya akan menciptakan siswa memiliki kemampuan berkomunikasi. Oleh sebab itu, penggunaan media pembelajaran interaktif perlu dikaji, apakah dapat meningkatkan hasil belajar kimia secara optimal.

Revolusi keempat itu telah merubah sistem pendidikan secara menyeluruh. Bahkan ada yang berpendapat secara ekstrem bahwa perkembangan itu mengarah kepada masyarakat tanpa sekolah, yaitu karena semua pesan dan informasi dapat disajikan melalui media dan setiap orang dapat memilioh sendiri pesan atau informasi yang diperlukan. Pendapat yang tepat sebenarnya adalah bahwa perkembangan media itu berpotensi untuk tumbuh dan berkembangnya masyarakat belajar. Oleh karena itu dalam setiap kegiatan belajar mengajar potensi media tidak mungkin diabaikan. (Miarso, 2004:456)

Menurut Dabbagh \& Ritland (2005:15) pembelajaran interaktif online adalah sistem belajar yang terbuka dan tersebar dengan menggunakan perangkat pedagogi (alat bantu pendidikan), yang dimungkinkan melalui internet dan teknologi berbasis jaringan untuk memfasilitasi pembentukan proses belajar dan pengetahuan melalui aksi dan interaksi yang berarti.

Media pembelajaran interaktif online dapat diartikan sebagai media yang dilengkapi 
dengan alat pengontrol yang dapat dioperasikan oleh pengguna (user), sehingga pengguna (user) dapat mengendalikan dan mengakses apa yang menjadi kebutuhan pengguna, misalnya mengunduh sumber-sumber untuk materi sifatsifat senyawa organik atas dasar gugus fungsi dan senyawa makromolekul pada pelajaran kimia. Keuntungan penggunaan media pembelajaran interaktif online adalah pembelajaran bersifat mandiri dan interaktivitas yang tinggi, mampu meningkatkan tingkat ingatan, memberikan lebih banyak pengalaman belajar, dengan teks, audio, video dan animasi yang semuanya digunakan untuk menyampaikan informasi, dan juga memberikan kemudahan menyampaikan, mengupdate isi, mengunduh, para siswa juga bisa mengirim email kepada siswa lain, mengirim komentar pada forum diskusi, memakai ruang chat, hingga link video conference untuk berkomunikasi langsung.

Selanjutnya Dabbagh dan Ritland mengatakan ada tiga komponen pada pembelajaran online yaitu : (a) model pembelajaran, (b) strategi instruksional dan pembelajaran, (c) media pembelajaran online. Ketiga komponen ini membentuk suatu keterkaitan interaktif, yang didalamya terdapat model pembelajaran yang tersusun sebagai suatu proses sosial yang menginformasikan desain dari lingkungan pembelajaran online, yang mengarah ke spesifikasi strategi instruksional dan pembelajaran yang secara khusus memungkinkan untuk memudahkan belajar melalui penggunaan teknologi pembelajaran. Pada gambar 1 dapat dilihat keterkaiatan ketiga komponen tersebut.

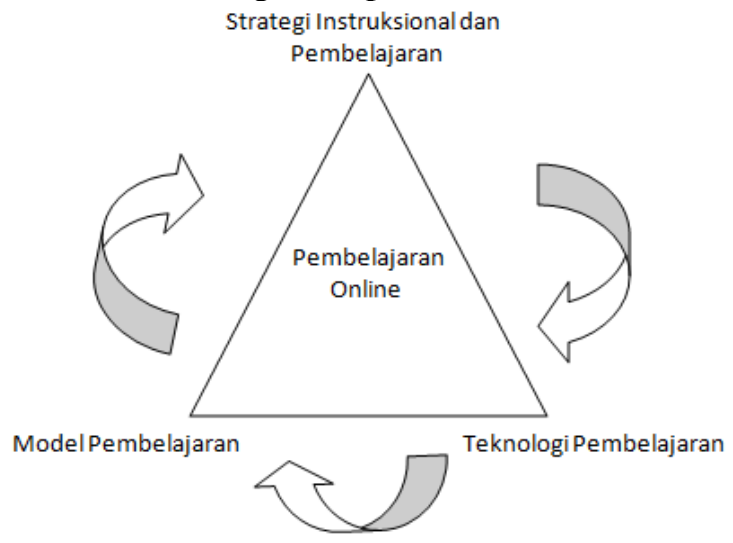

Gambar 1. Tiga Komponen Pembelajaran Online

Pengertian media pembelajaran interaktif online pada penelitian ini adalah penggunakan program E-Learning Moodle yang berisikan materi-materi pelajaran kimia, yang akan dilakukan secara online. Setiap siswa akan diberikan kesempatan untuk aktif dalam pembelajaran, baik untuk bertanya maupun untuk mengakses dan mengunduh materi-materi dari berbagai sumber melalui internet. Siswa juga dapat mengerjakan soal-soal yang ada serta dapat melihat hasil dari soal-soal yang telah dikerjakan, untuk setiap siswa mendapatkan soal secara acak.

Media pembelajaran interaktif offline dapat diartikan sebagai media yang tidak dilengkapi dengan alat pengontrol/navigasi yang dapat digunakan oleh pengguna (user). media ini berjalan secara berurutan (in sequence). Misalnya media persentasi yang pada umumnya tidak dilengkapi alat untuk mengontrol apa yang akan dilakukan oleh pengguna. Persentasi berjalan sekuensial sebagai garis lurus sehingga dapat disebut media linier dan biasanya digunakan bila jumlah audiens lebih dari satu orang, sebagai contoh dapat dapat diwujudkan dalam bentuk CD.

Muhammad (2007), komunikasi interpersonal adalah proses pertukaran informasi diantara seseorang dengan paling kurang seorang lainnya atau biasanya di antara dua orang yang dapat langsung diketahui balikannya. Soyomukti (2010:141) mengemukakan komunikasi interpersonal pada hakikatnya adalah interaksi antara seorang individu dan individu lainnya tempat lambanglambang pesan secara efektif digunakan, terutama dalam hal komunikasi antar-manusia menggunakan bahasa.

Devito (Soyomukti, 2010:142), menyatakan bahwa komunikasi interpersonal adalah "the process of sending and receiving message between two person, or among a small group of person, with some effect and some immidiate feedback" (proses pengiriman dan penerimaan pesan-pesan antara dua orang atau di antara sekelompok kecil orang-orang dengan beberapa efek dan beberapa umpan balik seketika). Dari definisi tersebut, komunikasi interpersonal bisa berlangsung antara dua orang yang saling bertemu, misalnya antara seorang mahasiswa dan dosen. Komunikasi interpersonal lebih efektif berlangsung jika berjalan secara dialogis, yaitu antara dua orang yang saling menyampaikan dan memberi pesan secara timbal balik.

Devito (2011:285) mengemukakan efektivitas komunikasi interpersonal dimulai dengan lima kualitas umum yang 
dipertimbangkan yaitu keterbukaan (openness), empati (empathy), sikap mendukung (supportiveness), sikap positif (positiveness), dan kesetaraan (equality).

Adapun tujuan penelitian ini secara umum adalah untuk memperoleh masukan tentang pengaruh penggunaan media pembelajaran interaktif, sedangkan secara khusus penelitian ini bertujuan untuk mengetahui: (1) Hasil belajar kelompok siswa yang diajar dengan menggunakan media pembelajaran interaktif online lebih tinggi dibandingkan dengan menggunakan media pembelajaran interaktif offline; dan (2) Hasil belajar kelompok siswa yang memiliki kemampuan komunikasi interpersonal terbuka lebih tinggi dibandingkan dengan kelompok siswa yang memiliki kemampuan komunikasi interpersonal tertutup. Adanya interaksi antara penggunaan media pembelajaran interaktif dengan komunikasi interpersonal dalam mempengaruhi hasil belajar Kimia.

Berdasarkan berbagai kajian teoretis, hasil penelitian yang relevan dan uraian kerangka berfikir, maka hipotesis dalam penelitian ini adalah sebagai berikut:

1. Kelompok siswa yang diajar dengan menggunakan media pembelajaran interaktif online memperoleh hasil belajar kimia lebih tinggi dari kelompok siswa yang diajar dengan menggunakan media pembelajaran interaktif offline.

2. Kelompok siswa yang memiliki komunikasi interpersonal terbuka memperoleh hasil belajar kimia lebih tinggi daripada kelompok siswa yang memiliki komunikasi interpersonal tertutup.

3. Terdapat interaksi antara pembelajaran dengan menggunakan media pembelajaran interaktif dan komunikasi interpersonal terhadap hasil belajar kimia.

\section{METODE PENELITIAN}

Penelitian ini di laksanakan di SMA Swasta Sutomo 2 Medan, Jalan Deli Indah IV No. 6 Medan, pada siswa kelas X semester genap. populasi dalam penelitian ini adalah seluruh siswa kelas X. yang terdiri dari 5 kelas, masing-masing kelas terdiri dari rata-rata 57 orang, secara keseluruhan populasi berjumlah 285 orang. Untuk teknik pengambilan sampel pada penelitian ini digunakan sampel kelompok secara acak (Cluster Random Sampling) melalui undian. Kelas sampel yang diambil adalah kelas X-2 dan kelas X-3 dengan jumlah sampel sebanyak 100 orang.
Metode yang diterapkan pada penelitian ini adalah metode quasi-eksperimen. Teknik analisis data yang digunakan untuk pengujian hipotesis adalah analisis varians (ANAVA) dua jalur (two-way Anova). Penggunaan teknik ini dimaksudkan agar hasil tes akhir yang dicapai oleh subjek penelitian benar-benar karena pengaruh dari perlakuan yang diberikan dalam proses penelitian dengan taraf signifikansi $\alpha=$ 0,05 . Jika hasil pengujian menunjukkan terdapatnya interaksi maka perlu dilakukan uji lanjut. Dalam penggunaan ANAVA dua jalur harus memenuhi syarat sebagai berikut: (1) data yang digunakan harus berdistribusi normal, sehingga perlu dilakukan uji normalitas dengan menggunakan uji Lillifors, (2) data harus memiliki varians populasi homogen, sehingga dilakukan uji homogenitas varians dengan menggunakan uji Fisher dan uji Bartlet.

Untuk keperluan pengujian hipotesis perlu dirumuskan hipotesis secara statistik yaitu

1. Ho : $\mu_{\mathrm{A} 1}=\mu_{\mathrm{A} 2}$

$\mathrm{Ha}: \mu_{\mathrm{A} 1}>\mu_{\mathrm{A} 2}$

2. Ho $: \mu_{\mathrm{B} 1}=\mu_{\mathrm{B} 2}$

$\mathrm{Ha}: \mu_{\mathrm{B} 1}>\mu_{\mathrm{B} 2}$

3. Ho : $\mathrm{A} \times \mathrm{B}=0$

$\mathrm{Ha}: \mathrm{A} \times \mathrm{B} \neq 0$

Keterangan :

$\mu_{\mathrm{A} 1}=$ Hasil belajar Kimia siswa yang diajar dengan menggunakan media interaktif online

$\mu_{\mathrm{A} 2}=$ Hasil belajar Kimia siswa yang diajar dengan menggunakan media interaktif offline

$\mu_{\mathrm{B} 1}=$ Hasil belajar Kimia siswa yang memiliki komunikasi interpersonal terbuka

$\mu_{\mathrm{B} 2}=$ Hasil belajar Kimia siswa yang memiliki komunikasi interpersonal tertutup

$\mathrm{A} \times \mathrm{B}=$ Interaksi antara penggunaan media interaktif dengan komunikasi interpersonal

\section{HASIL DAN PEMBAHASAN \\ Hasil}

Setelah dilakukan pengujian kedua persyaratan analisis yakni uji normalitas dan uji homogenitas, maka dapat dipastikan bahwa persyaratan yang harus dipenuhi oleh data penelitian dalam rangka penggunaan teknik analisis varians (ANAVA) telah dipenuhi, maka teknik analisis tersebut telah dapat digunakan. 
Tabel 1. Data Hasil Belajar Kimia Siswa

\begin{tabular}{|c|c|c|c|c|c|c|}
\hline \multirow{2}{*}{$\begin{array}{c}\text { Komunikasi } \\
\text { Interpersonal ( } \mathrm{B} \text { ) }\end{array}$} & \multicolumn{4}{|c|}{ Media Interaktif } & \multirow{2}{*}{\multicolumn{2}{|c|}{ Total }} \\
\hline & \multicolumn{2}{|c|}{ Online $\left(\mathrm{A}_{1}\right)$} & \multicolumn{2}{|c|}{ Offline $\left(\mathrm{A}_{2}\right)$} & & \\
\hline \multirow{5}{*}{ KI Terbuka $\left(B_{1}\right)$} & $\mathrm{n}_{\mathrm{A} 1 \mathrm{~B} 1}$ & 28 & $\mathrm{n}_{\mathrm{A} 2 \mathrm{~B} 1}$ & 26 & $\mathrm{n}_{\mathrm{t}}$ & 54 \\
\hline & $\bar{X}_{\mathrm{A} 1 \mathrm{~B} 1}$ & 35.143 & $\overline{\bar{X}}_{\mathrm{A} 2 \mathrm{~B} 1}$ & 30.192 & $\bar{X}_{\mathrm{t}}$ & 32.648 \\
\hline & SD & 2.438 & SD & 2.446 & SD & 3.406 \\
\hline & $\Sigma \mathrm{X}$ & 981 & $\sum \mathrm{X}$ & 784 & $\Sigma \mathrm{X}$ & 1765 \\
\hline & $\Sigma X^{2}$ & 34525 & $\Sigma X^{2}$ & 23776 & $\Sigma \mathrm{X}^{2}$ & 58301 \\
\hline \multirow{5}{*}{ KI Tertutup ( $\left.\mathrm{B}_{2}\right)$} & $\overline{\mathrm{n}_{\mathrm{A} 1 \mathrm{~B} 2}}$ & 22 & $\overline{\mathrm{n}_{\mathrm{A} 2 \mathrm{~B} 2}}$ & 24 & $\mathrm{n}_{\mathrm{t}}$ & 46 \\
\hline & $\bar{X}_{\mathrm{A} 1 \mathrm{~B} 2}$ & 29.318 & $\bar{X}_{\text {А2B2 }}$ & 32.583 & $\bar{X}_{\mathrm{t}}$ & 31.065 \\
\hline & SD & 2.538 & SD & 2.535 & SD & 3.153 \\
\hline & $\Sigma \mathrm{X}$ & 647 & $\Sigma \mathrm{X}$ & 782 & $\Sigma \mathrm{X}$ & 1429 \\
\hline & $\Sigma X^{2}$ & 19145 & $\Sigma \mathrm{X}^{2}$ & 25632 & $\Sigma \mathrm{X}^{2}$ & 44777 \\
\hline \multirow{5}{*}{ Total } & $\overline{\mathrm{n}_{\mathrm{t}}}$ & 50 & $\overline{\mathrm{n}_{\mathrm{t}}}$ & $\overline{50}$ & $\overline{\mathrm{n}_{\text {tot }}}$ & 100 \\
\hline & $\bar{X}$ & 32,540 & $\bar{X}$ & 31.340 & $\bar{X}_{\text {Tot }}$ & 31.940 \\
\hline & SD & 3,602 & SD & 2.853 & $\mathrm{SD}$ & 3.242 \\
\hline & $\Sigma \mathrm{X}$ & 1628 & $\Sigma \mathrm{X}$ & 1566 & $\Sigma \mathrm{X}$ & 3194 \\
\hline & $\Sigma X^{2}$ & 53670 & $\Sigma \mathrm{X}^{2}$ & 49408 & $\Sigma X^{2}$ & 103078 \\
\hline
\end{tabular}

Hasil perhitungan ANAVA seperti yang ditunjukkan dalam Tabel 2 adalah rangkuman analisis faktorial $2 \times 2$.

Tabel 2. Rangkuman Analisis Faktorial 2x2

\begin{tabular}{|l|r|c|r|c|c|c|}
\hline \multicolumn{1}{|c|}{ Sumber Varians } & \multicolumn{1}{c|}{ JK } & Dk & \multicolumn{1}{c|}{ RJK } & $F_{\text {hitung }}$ & $F_{\text {tabel }}$ & Kesimpulan \\
\hline Multimedia Pembelajaran & 38.44 & 1 & 38.44 & 6.596 & 3.94 & Signifikan \\
Komunikasi Interpersonal & 65.19 & 1 & 65.19 & 11.18 & 3.94 & Signifikan \\
Interaksi & 398.51 & 1 & 398.51 & 68.38 & 3.94 & Signifikan \\
\hline Antar kelompok & 502.14 & 3 & 38.44 & & & \\
Dalam kelompok & 559.5 & 96 & 5.83 & & & \\
\hline Total & 1061.64 & 99 & & & & \\
\hline
\end{tabular}

Berdasarkan rangkuman pada tabel 2 maka akan dirinci pengujian hipotesis sebagai berikut:

\section{Hipotesis Pertama.}

Pengujian hipotesis pertama yang menyatakan hasil belajar kimia siswa yang dibelajarkan dengan media pembelajaran interaktif online, lebih tinggi daripada hasil belajar siswa yang diajarkan dengan media pembelajaran interaktif offline, hipotesis statistiknya adalah:

$$
\begin{aligned}
& \text { Ho }: \mu_{\mathrm{A} 1}=\mu_{\mathrm{A} 2} \\
& \text { Ha }: \mu_{\mathrm{A} 1}>\mu_{\mathrm{A} 2}
\end{aligned}
$$

Pernyataan hipotesis tersebut adalah :

Ho =Rata-rata hasil belajar kimia siswa yang dibelajarkan dengan menggunakan media pembelajaran interakatif online lebih kecil atau sama dengan rata rata hasil belajar kimia siswa yang dibelajarkan dengan media pembelajaran interakatif offline

$\mathrm{Ha}=$ Siswa yang dibelajarkan dengan menggunakan media pembelajaran interakatif online memperoleh rata-rata hasil belajar kimia lebih tinggi dari pada siswa yang dibelajarkan dengan media pembelajaran interakatif offline

Berdasarkan perhitungan ANAVA faktorial $2 \times 2$ diperoleh $\mathrm{F}_{\text {hitung }}=6.596$ sedangkan nilai $\mathrm{F}_{\text {tabel }}=3.94$ untuk dk $(1,96)$ dan taraf nyata $\alpha=0,05$. Ternyata nilai $F_{\text {hitung }}=6.596>F_{\text {tabel }}=$ 3.94, pengujian hipotesis menolak Ho dan menerima $\mathrm{Ha}$, sehingga ditarik kesimpulan bahwa hasil belajar kimia siswa yang dibelajarkan dengan media pembelajaran interaktif online lebih tinggi dibandingkan dengan media pembelajaran interaktif offline teruji kebenarannya secara empirik. Hal ini juga terlihat dari rata-rata hasil belajar kimia yang dibelajarkan dengan media pembelajaran 
interaktif online ( $\bar{X}=35.143$ ) lebih tinggi dari hasil belajar kimia yang dibelajarkan dengan media pembelajaran interaktif offline ( $\bar{X}=$ 30.192).

\section{Hipotesis Kedua.}

Pengujian hipotesis kedua yang menyatakan : hasil belajar kimia siswa yang memiliki komunikasi interpersonal terbuka, lebih tinggi daripada hasil belajar kimia siswa yang memiliki komunikasi interpersonal tertutup, hipotesis statistiknya adalah:

$$
\begin{aligned}
& \text { Ho: } \mu_{\mathrm{B} 1}=\mu_{\mathrm{B} 2} \\
& \text { Ha }: \mu_{\mathrm{B} 1}>\mu_{\mathrm{B} 2}
\end{aligned}
$$

Pernyataan hipotesis tersebut adalah :

Ho =Siswa yang memiliki komunikasi interpersonal terbuka memperoleh ratarata hasil belajar kimia lebih rendah atau sama dengan siswa yang memiliki komunikasi interpersonal tertutup

$\mathrm{Ha}=$ Siswa yang memiliki komunikasi interpersonal terbuka memperoleh hasil belajar kimia lebih tinggi daripada siswa yang memiliki komunikasi interpersonal tertutup

Berdasarkan perhitungan ANAVA faktorial $2 \times 2$ diperoleh $\mathrm{F}_{\text {hitung }}=11.18$ sedangkan nilai $\mathrm{F}_{\text {tabel }}=3.94$ untuk dk $(1,96)$ dan taraf nyata $\alpha=0,05$. Ternyata nilai $F_{\text {hitung }}=11.18>\mathrm{F}_{\text {tabel }}=$ 3.94, pengujian hipotesis menolak Ho dan menerima Ha, sehingga ditarik kesimpulan bahwa hasil belajar kimia siswa yang memiliki komunikasi interpersonal terbuka lebih tinggi dibanding siswa yang memiliki komunikasi interpersonal tertutup teruji kebenarannya secara empirik. Hal ini juga terlihat dari ratarata hasil belajar kimia yang memiliki komunikasi interpersonal terbuka ( $\bar{X}=32.648$ ) lebih tinggi dari hasil belajar kimia siswa yang memiliki komunikasi interpersonal tertutup $(\bar{X}=31.109)$.

\section{Hipotesis Ketiga.}

Pengujian hipotesis yang ketiga yaitu: terdapat interaksi antara media pembelajaran interaktif dan komunikasi interpersonal dalam meningkatkan hasil belajar kimia.

$$
\begin{aligned}
& \text { Ho: A X B }=0 \\
& \text { Ha : A X B } \neq 0
\end{aligned}
$$

Pernyataan hipotesis tersebut adalah :

Ho = Tidak terdapat interaksi antara media pembelajaran interaktif dan komunikasi interpersonal terhadapa hasil belajar kimia siswa.

$\mathrm{Ha}=$ Terdapat interaksi antara media pembelajaran interaktif dan komunikasi interpersonal terhadapa hasil belajar kimia siswa.

Berdasarkan perhitungan ANAVA faktorial $2 \times 2$ diperoleh $F_{\text {hitung }}=68.38$ sedangkan nilai $\mathrm{F}_{\text {tabel }}=3.94$ untuk dk $(1,96)$ dan taraf nyata $\alpha=0,05$. Ternyata nilai $F_{\text {hitung }}=68.38>\mathrm{F}_{\text {tabel }}=$ 3.94, pengujian hipotesis menolak Ho dan menerima $\mathrm{Ha}$, sehingga ditarik kesimpulan bahwa terdapat interaksi antara media pembelajaran interaktif dan komunikasi interpersonal terhadap hasil belajar kimia siswa, teruji kebenarannya secara empirik.

Untuk melihat perbandingan kombinasi interaksi antara media pembelajaran interaktif dan komunikasi interpersonal terhadap hasil belajar kimia, maka dilakukan uji lanjut dengan Uji Scheffe. Perhitungan untuk uji Scheffe. Rangkuman hasil perhitungan uji Scheffe dapat dilihat pada Tabel 3 .

Tabel 3. Rangkuman Hasil Uji Scheffe

\begin{tabular}{|l|c|c|c|}
\hline \multicolumn{2}{|c|}{ Hipotesis Statistik } & $F_{\text {hitung }}$ & $F_{\text {tabel }}(3,96) \alpha=0,05$ \\
\hline Ho: $\mu_{\mathrm{A} 1 \mathrm{~B} 1}=\mu_{\mathrm{A} 2 \mathrm{~B} 1}$ & Ha: $\mu_{\mathrm{A} 1 \mathrm{~B} 1}>\mu_{\mathrm{A} 2 \mathrm{~B} 1}$ & 11.45 & 2.70 \\
\hline Ho: $\mu_{\mathrm{A} 1 \mathrm{~B} 1}=\mu_{\mathrm{A} 1 \mathrm{~B} 2}$ & Ha: $\mu_{\mathrm{A} 1 \mathrm{~B} 1}>\mu_{\mathrm{A} 1 \mathrm{~B} 2}$ & 12.31 & 2.70 \\
\hline Ho: $\mu_{\mathrm{A} 1 \mathrm{~B} 1}=\mu_{\mathrm{A} 2 \mathrm{~B} 2}$ & Ha: $\mu_{\mathrm{A} 1 \mathrm{~B} 1}>\mu_{\mathrm{A} 2 \mathrm{~B} 2}$ & 5.68 & 2.70 \\
\hline Ho: $\mu_{\mathrm{A} 2 \mathrm{~B} 1}=\mu_{\mathrm{A} 1 \mathrm{~B} 2}$ & Ha: $\mu_{\mathrm{A} 2 \mathrm{~B} 1}<\mu_{\mathrm{A} 1 \mathrm{~B} 2}$ & 1.79 & 2.70 \\
\hline Ho: $\mu_{\mathrm{A} 2 \mathrm{~B} 2}=\mu_{\mathrm{A} 2 \mathrm{~B} 2}$ & Ha: $\mu_{\mathrm{A} 2 \mathrm{~B} 1}>\mu_{\mathrm{A} 2 \mathrm{~B} 2}$ & 5.12 & 2.70 \\
\hline Ho: $\mu_{\mathrm{A} 2 \mathrm{~B} 1}=\mu_{\mathrm{A} 2 \mathrm{~B} 2}$ & Ha: $\mu_{\mathrm{A} 2 \mathrm{~B} 2}>\mu_{\mathrm{A} 1 \mathrm{~B} 2}$ & 6.43 & 2.70 \\
\hline
\end{tabular}

Berdasarkan Tabel 3 di atas terdapat 1 dari enam kombinasi yang dibandingkan menunjukkan hasil yang tidak signifikan, hal ini disebabkan oleh tidak terdapatnya perberdaan yang signifikan antara rata-rata hasil belajar 
kimia dalam sel. Dari hasil uji Scheffe di atas diperoleh simpulan:

(1) Rata-rata hasil belajar kimia siswa yang dibelajarkan dengan media pembelajaran interaktif online berdasarkan komunikasi interpersonal terbuka lebih tinggi dibandingkan dengan rata-rata hasil belajar kimia siswa yang dibelajarkan dengan media pembelajaran interaktif offline berdasarkan komunikasi interpersonal tertutup.

(2) Rata-rata hasil belajar kimia siswa yang dibelajarkan dengan media pembelajaran interaktif online berdasarkan komunikasi interpersonal terbuka lebih tinggi dibanding dengan rata-rata hasil belajar kimia siswa dengan media pembelajaran interaktif online berdasarkan komunikasi interpersonal tertutup.

(3) Rata-rata hasil belajar kimia siswa yang dibelajarkan dengan media pembelajaran interaktif online berdasarkan komunikasi interpersonal terbuka lebih tinggi dibandingkan dengan rata-rata hasil belajar kimia siswa yang dibelajarkan dengan media pembelajaran interaktif offline berdasarkan komunikasi interpersonal tertutup.

(4) Rata-rata hasil belajar kimia siswa yang dibelajarkan dengan media pembelajaran interaktif online berdasarkan komunikasi interpersonal tertutup lebih rendah dibanding dengan rata-rata hasil belajar kimia siswa yang dibelajarkan dengan media pembelajaran interaktif offline berdasarkan komunikasi interpersonal terbuka.

(5) Rata-rata hasil belajar kimia siswa yang dibelajarkan dengan media pembelajaran interaktif offline berdasarkan komunikasi interpersonal terbuka lebih tinggi dibandingkan dengan rata-rata hasil belajar kimia siswa yang dibelajarkan dengan media pembelajaran interaktif offline berdasarkan komunikasi interpersonal tertutup.

(6) Rata-rata hasil belajar kimia siswa dengan media pembelajaran interaktif online berdasarkan komunikasi interpersonal tertutup lebih tinggi dibandingkan dengan rata-rata hasil belajar kimia siswa dengan media pembelajaran interaktif offline berdasarkan komunikasi interpersonal tertutup.

Hasil pengujian lanjut di atas, menunjukkan adanya interaksi antara media pembelajaran interaktif dan komunikasi interpersonal terhadap hasil belajar kimia siswa SMA Swasta Sutomo 2 Medan.

Interaksi media pembelajaran dan komunikasi interpersonal dapat ditunjukkan seperti pada Gambar 1 berikut ini :

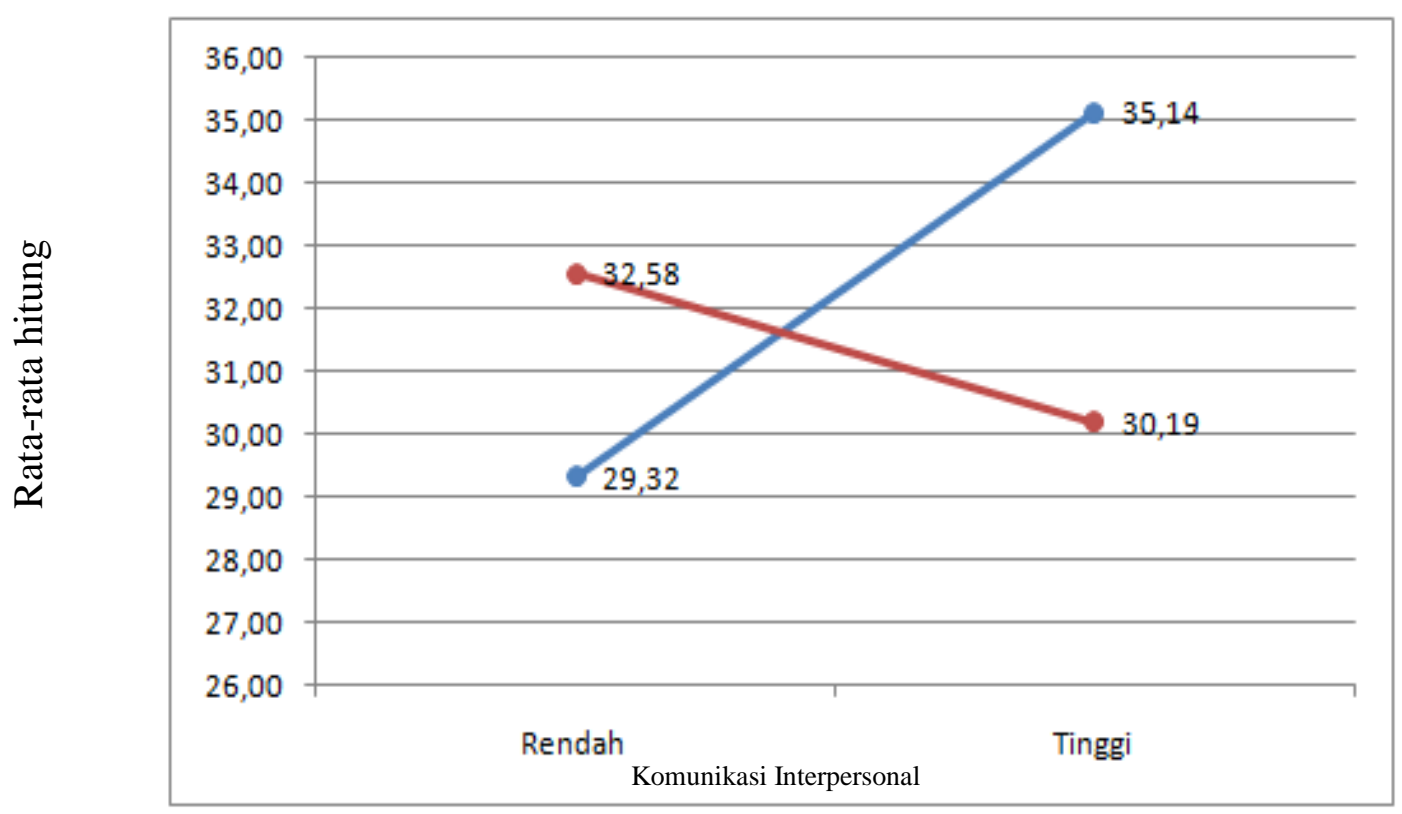

Gambar 1. Interaksi Antara Pembelajaran Dengan Menggunakan Media Pembelajaran Interaktif Dan Komunikasi Interpersonal Terhadap Hasil Belajar Kimia

Berdasarkan hasil pengujian hipotesis ketiga yang menyatakan adanya interaksi antara media pembelajaran interaktif dengan komunikasi interpersonal, maka perlu dilakukan 
uji perbedaan rata-rata antara dua proposi. Gambar 1 menunjukkan pengaruh dan interaksi dari media pembelajaran dan komunikasi interpersonal terhadap hasil belajar kimia yang diperoleh siswa, rata rata hasil belajar kimia yang dibelajarkan dengan media pembelajaran interaktif online lebih tinggi dibandingkan dengan media pembelajaran interaktif offline. Penelitian ini juga membuktikan faktor komunikasi interpersonal sebagai salah satu karakteristik siswa perlu diperhatikan karena terbukti bahwa komunikasi interpersonal siswa berpengaruh terhadap hasil belajar kimia.

\section{Pembahasan}

Perbedaan Hasil Belajar Kimia Antara Siswa Yang Dibelajarkan Dengan Menggunakan Media Pembelajaran Interaktif Online Dan Siswa Yang Dibelajarkan Dengan Menggunakan Media Interaktif Offline. Dari hasil pengolahan data penelitian yang dilakukan, terdapat perbedaan hasil belajar kimia antara siswa yang dibelajarkan dengan menggunakan media interaktif online dan siswa yang dibelajarkan dengan menggunakan media pembelajaran interaktif offline yaitu ratarata hasil belajar kimia siswa yang dibelajarkan dengan menggunakan media pembelajaran interaktif online lebih tinggi dibandingkan dengan siswa yang dibelajarkan dengan menggunakan media pembelajaran offline. Hal ini dapat dilihat dari hasil nilai rata-rata kimia siswa yang yang diajar dengan media pembelajaran interaktif online yaitu sebesar 35.143, sedangkan hasil nilai rata-rata kimia siswa yang yang diajar dengan media pembelajaran interaktif offline sebesar 30.192. Dari data ini membuktikan bahwa penggunaan media pembelajaran interaktif online lebih baik dalam meningkatkan pengetahuan siswa dalam pembelajaran kimia daripada penggunaan media pembelajaran interaktif offline. Ini beralasan, karena media pembelajaran interaktif online adalah sistem belajar yang terbuka dan tersebar dengan menggunakan perangkat pedagogi (alat bantu pendidikan), yang dimungkinkan melalui internet dan teknologi berbasis jaringan untuk memfasilitasi pembentukan proses belajar dan pengetahuan melalui aksi dan interaksi yang berarti (Dabbagh dan Ritland 2005:15).

Penggunaan media pembelajaran interaktif online dalam pembelajaran kimia memungkinkan siswa untuk berinteraksi langsung dan melakukan kontrol langsung pada sumber informasi, sehingga siswa dapat mengendalikan dan mengakses apa yang menjadi kebutuhannya, misalnya mengunduh sumber-sumber untuk materi sifat-sifat senyawa organik atas dasar gugus fungsi dan senyawa makromolekul pada pelajaran kimia. Pembelajaran dengan media interaktif online juga memungkinkan guru bebas melakukan interaksi dengan siswa sehingga pembelajaran tersebut bersifat interaktif yang membuat pembelajaran terfokus pada informasi yang sedang dipelajari.

Hal tersebut di atas berbeda dengan pembelajaran menggunakan media pembelajaran interaktif offline, siswa tidak berinteraksi langsung pada sumber informasi dan pembelajaran didominasi oleh guru yang menyajikan informasi secara linier atau satu arah. Hal ini terjadi karena pada media pembelajaran interaktif offline siswa mendapatkan sumber informasi hanya dari guru dan materi-materi yang telah ada pada program E-Learning Moodle, siswa tidak dapat mengakses ataupun mengunduh melalui internet. Siswa dapat aktif bertanya hanya seputar materi-materi yang telah ada. Secara ringkas dapat dinyatakan bahwa sumber-sumber informasi yang didapat hanya pada informasi yang telah ada sebelumnya, dibandingkan dengan penggunaan media pembelajaran interaktif online. Pembelajaran dengan menggunakan media interaktif offline menempatkan guru menggunakan kontrol pembelajaran dengan aktif, sementara siswa relatif pasif menerima dan mengikuti apa yang disampaikan guru. Guru menyampaikan materi secara terstruktur dengan harapan materi pelajaran yang disampaikan dapat dikuasai dengan baik dengan terfokus kepada kemampuan akademik.

Tetapi pada data rata-rata hasil belajar kimia siswa yang dibelajarkan dengan media pembelajaran interaktif online berdasarkan komunikasi interpersonal tertutup lebih rendah dibanding dengan rata-rata hasil belajar kimia siswa yang dibelajarkan dengan media pembelajaran interaktif offline berdasarkan komunikasi interpersonal terbuka, hal ini terjadi mungkin dikarenakan ada faktor lain misalnya kondisi pembelajaran yang tidak baik, guru yang ditugaskan tidak memahami perlakuan sepenuhnya, kondisi pada saat siswa diberikan perlakuan dan sebagainya.

Walaupun dalam penelitian ini secara umum diperoleh data bahwa hasil belajar kimia siswa lebih tinggi jika dibelajarkan dengan media pembelajaran interaktif online daripada 
hasil belajar kimia siswa yang dibelajarkan dengan media pembelajaran interaktif offline. Namun dalam pelaksanaannya kedua media pembelajaran interaktif ini telah mampu meningkatkan pemahaman dan hasil belajar kimia siswa. Sehingga dapat disimpulkan bahwa hasil belajar kimia siswa yang dibelajarkan dengan menggunakan media pembelajaran interaktif online lebih tinggi dibandingkan dengan hasil belajar kimia siswa yang dibelajarkan dengan menggunakan media pembelajaran interaktif offline. Hal ini sesuai dengan penelitian sebelumnya yang telah dilaksanakan oleh Sony (2011) yang menyimpulkan bahwa hasil belajar TIK siswa yang dibelajarkan dengan menggunakan multimedia CD interaktif lebih baik secara signifikan dibandingkan dengan hasil belajar TIK siswa yang dibelajarkan dengan menggunakan multimedia VCD.

Perbedaan Hasil Belajar Kimia Antara Siswa Yang Memiliki Komunikasi Interpersonal Terbuka Dan Siswa Yang Memiliki Komunikasi Interpersonal Tertutup. Dari hasil penelitian ini, juga menunjukkan bahwa rata-rata hasil belajar kimia siswa yang memiliki komunikasi interpersonal terbuka lebih tinggi daripada hasil belajar kimia siswa yang memiliki komunikasi interpersonal tertutup. Hal ini mengindikasikan bahwa siswa yang memiliki komunikasi interpersonal terbuka lebih mampu memahami pelajaran kimia dibandingkan dengan siswa yang memiliki komunikasi interpersonal tertutup. Hal ini beralasan, karena siswa yang memiliki komunikasi interpersonal terbuka memiliki karakteristik: (1) keterbukaan (openness), (2) empati (empathy), (3) sikap mendukung (supportive-ness), (4) sikap positif (positiveness) dan (5) kesetaraan (equality), sedangkan siswa yang memiliki komunikasi interpersonal tertutup sebaliknya (Devito:2011:285)

Hasil Penelitian ini mendukung penelitian sebelumnya yang dilakukan oleh Erlinawati (2009) tentang Pengaruh Strategi Pembelajaran Dan Komunikasi Interpersonal Terhadap Hasil Belajar PAI, menemukan bahwa pengaruh komunikasi interpersonal terhadap hasil belajar sangat signifikan dan ditemukan bahwa siswa yang memiliki komunikasi interpersonal tinggi memiliki skor rata-rata lebih tinggi daripada siswa yang memiliki komunikasi interpersonal rendah.

Interaksi antara media Pembelajaran dan Komunikasi Interpersonal Terhadap Hasil
Belajar Kimia. Temuan penelitian menunjukkan bahwa terdapat interaksi antara media pembelajaran interaktif dan komunikasi interpersonal terhadap hasil belajar kimia. Siswa yang memiliki komunikasi interpersonal terbuka yang dibelajarkan dengan media pembelajaran interaktif online memperoleh hasil belajar kimia yang lebih tinggi daripada siswa yang memiliki komunikasi interpersonal terbuka yang dibelajarkan dengan menggunakan media pembelajaran interaktif offline. Demikian pula siswa yang memiliki komunikasi interpersonal tertutup yang dibelajarkan dengan menggunakan media pembelajaran interaktif online memperoleh hasil belajar kimia yang lebih rendah dibandingkan dengan siswa yang dibelajarkan dengan menggunakan media pembelajaran interaktif offline, meskipun dalam penelitian ini tidak terdapat perbedaan yang signifikan. Hal ini mengindikasikan adanya interaksi antara penggunaan media pembelajaran interaktif dengan komunikasi interpersonal terhadap hasil belajar kimia siswa.

Media pembelajaran interaktif merupakan media pembelajaran yang menuntut adanya interaksi langsung dengan sumber informasi sehingga dapat meningkatkan rasa keingintahuan, minat, kreatifitas, motivasi belajar bagi siswa yang memilki komunikasi interpersonal terbuka. Media pembelajaran interaktif online adalah sistem belajar yang terbuka dan tersebar dengan menggunakan perangkat pedagogi (alat bantu pendidikan), yang dimungkinkan melalui internet dan teknologi berbasis jaringan untuk memfasilitasi pembentukan proses belajar dan pengetahuan melalui aksi dan interaksi yang berarti (Dabbagh dan Ritland:2005:15)

Sehingga bagi siswa yang memiliki komunikasi interpersonal terbuka akan terpacu untuk lebih giat belajar dan mampu mengendalian diri karena mereka selalu optimis untuk dapat mengetahui informasi tentang tujuan penerapan kimia dalam kehidupan sehari hari dan meningkatkan hasil belajarnya. Sedangkan siswa yang memilki komunikasi interpersonal tertutup mungkin akan merasa khawatir dan was-was kalau mereka tidak mampu mengikuti pembelajaran. Hal ini terjadi karena siswa dengan karakteristik komunikasi interpersonal tertutup akan termotivasi dan tertarik pada materi pembelajaran yang disajikan dengan menggunakan media atau alat bantu yang praktis, sederhana dan mudah dilakukan. Salah satunya adalah penggunaan 
media interaktif offline, siswa hanya dituntut mampu mengkaitan konsep-konsep sehingga dapat membentuk suatu informasi yang sesuai dengan kompetensi dasar yang telah ditetapkan.

Hasil Penelitian ini mendukung penelitian sebelumnya yang dilakukan oleh Sony (2011) tentang Pengaruh Penggunaan Multimedia Pembelajaran Dan Kecerdasan Emosional Siswa Terhadap Hasil Belajar TIK, menemukan bahwa hasil belajar TIK siswa yang dibelajarkan dengan menggunakan multimedia CD interaktif lebih baik secara signifikan dibandingkan dengan hasil belajar TIK siswa yang dibelajarkan dengan menggunakan multimedia VCD.

\section{PENUTUP \\ Simpulan}

Berdasarkan hasil penelitian dan pembahasan yang dikemukakan sebelumnya maka dalam penelitian ini dapat disimpulkan bahwa :

1. Penggunaan media pembelajaran interaktif online memberikan pengaruh terhadap hasil belajar kimia yang lebih tinggi bila dibandingkan dengan penggunaan media pembelajaran interaktif offline.

2. Hasil belajar kimia siswa yang memiliki komunikasi interpersonal terbuka lebih tinggi daripada hasil belajar kimia siswa yang memiliki komunikasi interpersonal tertutup.

3. Terdapat interaksi antara penggunaan media pembelajaran interaktif dan komunikasi interpersonal dalam mempengaruhi hasil belajar kimia siswa. Hal ini terbukti dari hasil uji lanjutan yang memberikan kesimpulan bahwa kelompok siswa yang memiliki komunikasi interpersonal terbuka memperoleh hasil belajar kimia lebih tinggi jika dibelajarkan dengan menggunakan media pembelajaran interakatif online daripada menggunakan media pembelajaran interaktif offline, sementara siswa yang memiliki komunikasi interpersonal tertutup lebih tinggi hasil belajarnya jika dibelajarkan dengan media pembelajaran interaktif offline daripada menggunakan media pembelajaran interaktif online.

\section{Saran}

Berdasarkan hasil dan temuan yang telah diuraikan pada kesimpulan serta implikasi hasil penelitian, maka disarankan beberapa hal sebagai berikut :
1. Kepada guru dalam memberikan pelajaran sebaiknya menggunakan media pembelajaran interaktif online, daripada menggunakan media pembelajaran interaktif offline. Hal ini berdasarkan hasil dari penelitian yaitu penggunaan media pembelajaran interaktif online memberikan pengaruh terhadap hasil belajar yang lebih tinggi bila dibandingkan dengan penggunaan media pembelajaran interaktif offline.

2. Kepada para guru agar memperhatikan komunikasi interpersonal yang yang dimiliki siswa. Dengan mengelompokkan siswa berdasarkan kelompok komunikasi interpersonal terbuka dan tertutup, maka guru dapat membedakan dalam memberikan pelajaran dengan menggunakan media pembelajaran interaktif yaitu menggunakan media pembelajaran interaktif online untuk kelompok siswa yang memiliki komunikasi terbuka dan media pembelajaran interaktif offline untuk siswa yang memiliki komunikasi interpersonal tertutup.

3. Untuk penelitian lebih lanjut pada penggunaan media pembelajaran interaktif disamping guru yang menjadi mitra peneliti, perlu untuk disosialisasikan terlebih dahulu kepada siswa bagaimana prosedur penggunaan media pembelajaran interaktif sehingga peggunaan waktu bisa seefisien mungkin dan efektifitas pembelajaran dapat tercapai.

4. Untuk peneliti lain yang meneliti tentang penggunaan media pembelajaran interaktif disarankan untuk menggunakan media pembelajaran interaktif yang memiliki kualitas kelayakan sama antara dua media interaktif yang dibandingkan sehingga hasil penelitian lebih akurat.

\section{DAFTAR PUSTAKA}

AECT, (1987). Defenisi Teknologi Pendidikan: Satuan Tugas Defenisi dan termologi. Jakarta: Rajawali.

Arsyad, A. (2005). Media Pembelajaran. Jakarta: Raja Grafindo Persada.

Borg. R. W. \& Gall M. D. (1989). Educational Research, An Introduction, Fifth Edition: Longman.

Dabbagh, N. \& Ritland. B. B. (2005). Online Learning, Concepts, Strategies And Application. Ohio: Pearson. 
DeVito. Joseph A. (2011). Komunikasi Antar manusia Edisi Kelima Alih Bahasa Maulana. Agus. Tangerang Selatan: Karisma

Dick. W \& Carey. L (2005). The Systemutic Design of Instruction Six Edition. USA: Pearson.

Djiwandono, S. E. (2006). Psikologi Pendidikan. Jakarta: Gramedia Wiasara.

Dryden, Gordon \& Vos. J. (2001). Revolusi Cara Belajar. Bandung: Kaifa.

Foster. Helen \& Cole . Jason (2008). Using Moodle Second Edition. USA: O'Reilly.

Hamid, A. (2009). Teori Belajar dan Pembelajaran. Medan: Unimed.

Heinich, R \& Molenda. M and Russel, D. J. (1985).Instructional Media and The New Technologies of Instruction. United State: John Willey \& Son.

Mayer, R. E. (2009). Multi Media Leartting Prinsip-Prinsip Dan APlikasi. Yogvakarta: Pustaka Pelajar Miarso, Y. (2004). Menyemai BettihT,eknolugi Pendidikanr. Jakarta: Rajawali,

Muchtarididan Justiana S.(2007). Kimia SMA Kelas X.Barrdung: Quadra.

Muhammad, A. (2007). Komunikasi Organisasi. Yogyakarta: Bumi Aksara'

Nasution, S. (2008). Berbagai Pendekatan Dalam Proses Belajar dan Mengaiar' Jakarta: Bumi Aksara.
Rada, R. (2001). Anderstanding Virtual Universities' USA: Intellect'

Rakhmat, J. (2004). Psikologi Komunikasi Bandung: PT' Remaja Rosdakarya'

Reigeluth, C.M. (1983). Instructional-Design Theories And Models: An Oierview of Their Current Status. London: Lawrence Erlbaum Associates Publishers.

Reigeluth, C. M. (1999). Instructional Design Theorie .And-Models : A New-Paradigm of Instructional Theory Volume 1 London: Lawrence Erlbaum Associates Pubiishers.

Rosenberg, Marc Jeffrey. (2001). E-Learning : Strategies For Delivering Knowledge In The Digital Era. USA : Mcgraw Hill'

Soyomukti, Nurani. (2010). Pengantar llmu Komunikasi. Yogyakarta: Ar-Ruzz Media.

Sunardi. (2007). Kimia Bilinggual SMA Kelas $X$. Bandung: Yrama Widya.

Yusuf, P. M. (2010). Komunikasi Instruksional Teori Dan Praktek Jakarta: Bumi Aksara

Sudrajat, Akhmad (2011). Hakikat Belajar (online). GEB/akhmadsudrdll wordpress.com/2008/01/31/hakikatbelaiar/, di akses pada tarrrggal 22 Pebruari 201 1, pukul 09.55 WIB.1 